\title{
Problems of Disclosure of Accounting Information in the Lists: Financial Speculation in Companies
}

\author{
Mah'd Al-jabali ${ }^{1} \&$ Haider Mohammad Ali Bni Ata $^{2}$ \\ ${ }^{1}$ Accounting Department, Al-Zaytoonah University of Jordan, Jordan \\ ${ }^{2}$ Philadelphia University, Jordan \\ Correspondence: Mah'd Al-jabali, Accounting Department, Al-Zaytoonah University of Jordan, Jordan. E-mail: \\ d.jabali@yahoo.com
}

$\begin{array}{ll}\text { Received: December 21, } 2013 & \text { Accepted: January 10, } 2014 \quad \text { Online Published: February 25, } 2014 \\ \text { doi:10.5539/ijef.v6n3p139 } & \text { URL: http://dx.doi.org/10.5539/ijef.v6n3p139 }\end{array}$

\begin{abstract}
The study aimed to measure and determine the expenses and revenues, assets and liabilities and equity and the distribution of profits in companies speculative Islamic as well as to identify the elements of disclosure of accounting information for decision makers of good and to achieve the use of researchers analysis method and stability to answer the study questions that follow.

i - How to measure and identify all of the revenues, expenses, assets, liabilities and owners' equity and disclosed in companies trading?

ii - How do you measure and determine the distribution of profits and losses and disclosed in companies trading?

iii - What are the basic components for the disclosure of accounting information in companies trading?

iv - What is the role of accounting disclosure to make accounting information more useful for decision makers in companies trading?
\end{abstract}

$\mathrm{v}$ - What are the rules of disclosure in companies trading?

The study found that accounting disclosure in speculative companies is through the Islamic view of accounting information and-easy ways to arrange and organize information in a logical manner keeping in view the nature of the accounting policies and accounting unit and the subsequent events in line with international accounting standards which will facilitate to the user good decision-making. And are identifying the elements of revenue and expenses to be disclosed in accordance with the requirements speculative companies prepare the income statement with a statement that the expenditure may be measured in cash or in kind per month or per year. May not be loading the income statement depreciation expense of fixed assets because it reduces the value of the net profit will be shared between the speculative and the owner of money and load it on the employer's share capital only, while consumption of assets intended for sale in the process of speculation can be downloaded on the proceeds of the financial period.

Use analytical methods to determine the expected revenues, as well as measuring the stock of goods last term on the basis of the price goes. And the profits are shared between the owner and speculator, according to the conditions that were agreed upon in the distribution of profits and not distributed until after the identification of capital and if the dissolution of the company given the capital of the owner first and then be sharing profits and losses will be on the owner only, and should be profit-known and distributed in shares of common between them and the presence of the parties to the contract and adopt the basic components of the accounting disclosure in corporate speculation on the financial information used for the purpose of accounting information, methods, and methods of the disclosure of accounting information.

Based on previous results the researchers recommended the re-inclusion laws relating to the disclosure of items that increase the level of transparency so as to compel companies to disclose speculative accounting policies and procedures in place And draw the attention of investors about the importance of information disclosed in companies speculation and its impact in the process of making investment decisions and the establishment of the organizers of the capital market to make efforts to increase disclosure of non-financial companies and work to strengthen and promote it such as the introduction aspects and new disclosures on human resources, and others. 
And the holding of workshops and conferences to raise awareness about the importance and the role of corporate speculation in the development of capital markets. And the importance of accounting disclosure in the guide and raise awareness of the accounting support to make a rational decision. And invite researchers to conduct more studies and research on companies speculation in general and the transparency of accounting disclosure on the face of particular, and applied to different sectors or insert other variables help to explain the different levels of transparency of disclosure between companies.

Keywords: disclosure, accounting, profits, speculative

\section{Study's Background and Its Important (General Framework)}

\subsection{Introduction}

Broking Companies in its general concept are organizations that aim to profit as other traditional companies do. This makes this company deals with different general sectors and the diversity of business operations which it practices according to the needs of the community within the framework of well defined which is Islamic law. This framework extends to all aspects of life that stimulate the community to work hard according to the concept of the verse.

In this context, social responsibility is also reflected in the work of Islamic companies, so it would call their owners to participate in its activities or it is the involved in their activities in the methods derived from the concepts of Islam, and thus works to create an active trading market in which their interests and the interests of society are balanced. And through Islamic companies seek to move away from the general line, which is used by traditional companies, Islamic companies seeking to direct its operations to serve the economic and social environment in various aspects of life and make profit considerations of social and economic considerations.

This is what justifies the need for accounting information published in the financial statements (representing the outputs of the accounting system) information is accurate and correct and suitable for all requirements according to the guidelines or rules governing these lists with the general purpose and beneficial to all parties, to make rational investment decisions. But what should these statements contain? In this search, we will investigate the problems to disclose financial statements and will be focusing on the terms of appropriate disclosure and its role in raising the efficiency of accounting information and make it acceptable to all in addition to the role of disclosure in strengthening trust between owners and brokers.

\subsection{The Problem of the Study}

The problem of the study lies in measurement and identifies the incomes and expenses in broking companies, calculate the return on the investment activities, the problem of measuring the distribution of the profit earned from these activities. The show at the end of the fiscal year, when preparing the financial statements of some accounting problems resulting from broking activities unfinished and other problems caused by some speculation goods that may be sold, and have not been paid for it. The problem of the study represented in following question broking:

i) How to measure, identify all of the income and expenses, assets, liabilities, owners' equity and disclosing about it in broking companies.

ii) How to measure, identify and distribute all profits and losses and disclosing about it in broking companies.

iii) What are the basic components for the disclosure of accounting information in broking companies?

iv) What is the role of accounting disclosure in making accounting information more useful to decision makers in broking companies?

v) What are the rules of disclosure of information in broking companies?

\subsection{The Importance of Research}

The importance of research come from the concept, the foundations of disclosure about accounting information in broking companies in terms of determining what the appropriate accounting disclosure, the basic components of disclosure about accounting information, rules of disclose information in accordance with International Accounting Standards, disclosure of accounting policies, the information that must be disclosed in the financial statements, and other aspects of required disclosure and supplied according to the Financial Accounting Standards.

The importance of research comes through a focus on information that must be disclosed in the financial statements and the role of this information in making decisions in broking companies.

The importance of research comes from the following questions: 
i) What are the basic components for the disclosure of accounting information in broking companies?

ii) What is the information that should be disclosure in financial statements in broking companies?

iii) How can the disclosure of accounting information in broking companies? What are the accounting policies to be disclosed?

\subsection{The Aims of the Research}

As a result of the increase in the size of broking companies that have an economic and social financial widespread impact in our modern society, which has led to concern in them by organizations, professional accounting associations and academic bodies. And what accounting companies suffer from broking in the weakness of the basic components for the disclosure of accounting information and accounting policies, for inability to provide specific answers to a number of problems facing the accountant.

The main question of the problem is to focus on the role of disclosure in raising the efficiency of accounting information, promote trust between the accounting unit and brokers, provide information to the parties concerned to ensure the decisions of economic and financial, taking into account the conditions of appropriate disclosure, its role in raising the efficiency of accounting information, make it acceptable to all in addition to the role of disclosure the strengthening of trust between owners and speculators.

\subsection{The Natural of the Study}

This study considers from analytical studies, that based on Inductive approach in the analysis and conclusion, through the study of a set of definitions, concepts and terms related to accounting disclosure in broking companies, review of the intellectual framework around the concept of disclosure, its role in the media accounting and appropriate disclosure requirements, then note the common interests between these groups and to reach the results according to scientific methodology.

\subsection{Limits of the Study}

a. Theoretical limits:

This study examined the disclosure problems of accounting information in the financial statements of broking companies in Islam and in accordance with the requirements of appropriate disclosure. It was the lack of studies on the problems of the disclosure of accounting information in the financial statements of broking companies in Islam, in line with international accounting standards, specifically when conducting a large study.

\section{b. Temporal limits:}

This study examined the problem of disclosure of accounting information in the financial statements of broking companies in Islam according to the International Accounting Standard No. (1) Presentation of Financial Statements for the year 1997.

\section{Theoretical Background of the Study Literature Review}

Companies in Islam are various, including business companies that rely on capital in the partnership, including the businesses or "Abdan" that rely on the craft or workmanship, including the Al-wojoh Company and that rely on the confidence of the people and do not have money or workmanship, but they are characterized by the experience and they have a good act, Abdan company and funds as a broking company - subject of the study. That will be talking about the theoretical framework for the study by identifying the broking companies, accounting disclosure and presentation models of studies about this topic and procedural definitions and assumptions of the study.

\subsection{Broking Companies}

It is called loan broking and it is a kind of companies in Islamic Sharia and it is economic and financial treatment, it is partnership in profit and not partnership in capital.

\subsubsection{The Broking Company Meaning}

Capital owner: the father of money or owner or partnership who give a currency: worker or broker or loaner. In broking, the money should be for the owner of it, and worker have not possess this money from its owner, Therefore, the worker is like the agent on money buys and sells to his owner, the profit between them, the worker is worthy profit because of his work, money must be for his owner and keep worker is like the agent. May not be a capital a debt or absent money, even if in custody of broker must be brought because the capital is to be understood and present sample. Disagreement between fuqaha in deliver the money to the worker which the broking is not valid until the capital deliver to broker, because it is not right to keep the integrate of the hands 
of who paid the money for non deliver even if condition for the demise of the hand of the Lord of the money from the money necessary, to come to work.

\subsubsection{Foundations of Broking}

Basic foundation for broking company which is : Acceptance and satisfaction between the contract parties (owner of money and broker), where the owner of money provides money for broker to work in it for trading so the broker accept that and profit according to the agreement between them.

The broking contract on basis of agency and integrate. The agency is between the owner of money and owner of work. Integrate means trustful worker, money in worker's custody, so if the money lose without any shortening the losing money will be on its owner and if broker died, Take money from his estate before its distribution.

Foundations of the broking are five:

i) Capital; ii) Work; iii) Form; iv) Owner of the money; v) Broker.

\subsubsection{Capital}

Some scholars see that the capital of the partnership must be cash and may not be debt or absent money. If it is in custody of broker it should bring it, because the capital should be present and existent sample. The disagreements lie in deliver the money to broker, Hanafi and Shafi' said that is not correct until the capital received by the broker because it is intehrate and may not deliver it to broker, it is not correct to keep the hands of payer on money for non-delivery. If the condition of keep the hands of wonder of money on money the broking will corrupted. The broking means the launch of the hands of a speculator in the disposition of money to work and trade (sale and purchase of goods and services) and this agreed upon jurists.

The scholars in broking capital stipulated four conditions to make the condition right:

a. Capital should be cash;

b. Capital should be Known;

c. Capital should not be debt;

d. Delivery of capital to the broker: this allows for broker form disposition of capital and launches its hand in disposition in it.

\subsubsection{Work}

Work may be absolute or restricted, absolute working: is what the broker do without the need for ( halfing ), hew has the freedom in disposition with all what he has in sales, purchases, and rental (goods and services). Restricted working not permits for broker to work alone without (halfing), according to conditions terminated as Leveraged, gift and donation or work in what was agreed in broking and may not broking be correct unless the permit of owner's money.

Broking may restrict in time and place or any other benefit restrict, because the basic conditions as much as possible, because the Prophet peace be upon him said: "Muslims in their own terms". The work should contain many conditions to become the broking correct, these conditions:

a. Work from the jurisdiction of the broker only: the scholar said that broker must jurisdiction in broking, he should not require from owner of money to participate with him and this condition is basic for broking and without it the broking will be corrupted. Hanbali stance sanctions this requirement.

b. Owner of money should not annoy the worker: the scholars said that owner of the money should not impose the broker. If the owner of the money does that then the broking will be corrupting.

c. Formulation: the formulations depend on positive and acceptance for contract between owner and broker.

d. The owner of the money, he is the owner and the body that entrusted the money to others, where legal capacity is required.

e. Broker: Is the agent for the owner by making the capacity in broker and broking valid from the child's guardian or guardian, including the guardian of the insane, fools and patient.

f. Agreement: the two brokers or more can involve in it, with one owner of the money or more but the resulted profit will be shared among them according to the condition. Scholars permit for broker the broke and share with him the servant of the money's owner in permit of owner and the profit between them.

2.1.2.3 Condition of Broking

a. Capital should be cash 
b. Capital should be known at contract and deliver it to broker, and empower him to disposition in it.

c. The profit should be common between them, may not for one of them to name the profit because it cuts Partnership.

d. Find out how much each of them profit of the half or a third or a quarter or a specific percentage and so on.

e. The deduction should be from profit not form capital.

\subsubsection{Termination of the Broking}

Broking is a contract between two parties and pacta sunt servanda. Party may terminate the partnership, should inform the owner so that the capital be dirhams and dinars, if represented money or demander to terminate the contract and shows the profit and loss, forbidding the act of madness and recoil before the expiration of the partnership.

\subsection{Accounting Disclosure}

Some scholars describe that accounting is a system for measurement and disclosure, where the accountant measures the different components of the financial statements, such as assets, liabilities, income and expenses. Then disclose the results of the measurement process in the form of information provided to read the financial statements, and subject information resulting from the measurement and disclosure of accounting for quality characteristics of accounting information. Disclosure is a fundamental pillar of the groups interested in the performance of companies, whether these categories shareholders or investors, the disclosure provides useful information in making investment decisions, this is achieved through the annual reports of the companies or disclosures across different communication channels such as the media or regulators of the capital market.

\subsubsection{Characteristics of Accounting Information}

Characteristics of accounting information divided to basic and secondary characteristics as the following:

\subsubsection{Basic Characteristics for Information}

\section{a. Relevance:}

It means the ability of accounting information to influence the decision and link information to work or use for which it found a link with desirable result for achievement. In order to be suitable information it has to have a predictive capability and can validate expectations and past events so information must be prepared so that reach to users in a timely manner.

\section{b. Reliability:}

It means the possibility of relying on reliable accounting information in the decision-making process. until this property available must be verifiable information to be of any significance specific information and have their independence regardless of who prepared by or for use and be viewable sincere and integrate. As well as accounting information must be characterized by any impartial not be biased in favor of a group of individuals at the expense of another group.

\subsubsection{Secondary Characteristics for Information}

Secondary characteristics for accounting information consider complementary to the basic characteristics in order to generate useful and meaningful information, these characteristics have the ability to contribute to the rational decision-making and these characteristics are:

\section{a. Comparability:}

So as to be comparable information should be used in the methods and uniform accounting rules so that it can identify the similarities and differences in the economic circumstances surrounding the unit. Different reasons give mixed results about the same facts and economic events leading to misleading results and misunderstanding about the allocation of economic resources.

\section{b. Consistency:}

This characteristic interact with the previous property, which means consistency and uniformity in the application of methods and accounting rules from time to time, which gives the possibility of comparing the results of the unit over time. In general, the characteristics of accounting information are characterized by the honesty in the expression about the possibility of phenomena installation of information.

\subsubsection{The Concept of Disclosure}

Accounting media requires providing decision makers with influential adequate information in determining the 
profits of the company and its financial position. The financial statements are the basic pillar for the disclosure, as observed in the preparation of generally accepted accounting principles, classification, standardization and comparisons, as well as notes, which include the financial statements of others and contained in the financial statements such as methods of evaluating inventory, processing expenses of maintenance, repair, conversions of foreign currencies, methods of depreciation, events occurring after the preparation of the budget, changes in accounting policy, clarifications that contain information not contained in the notes, financial statements that are complements it assurances on one asset or the market price or the cost of the stock of commodity and all this increases the confidence of the beneficiaries of the process of disclosure.

It is necessary to analyze the assets, depreciation, expense statement and the value of sales and cost in the form of statistical tables that show the reader the development of the project activity and the activities of current and future events and non-financial affect it in the future, such as energy production and any problems related to production and distribution. The suitability of the information most relevant should summarize by amount units which clarify in financial statements but descriptive information should appear in the form of guidance notes published in addition to the financial statements.

Disclosure is appropriate when expressing useful information to the decision maker when it is not this information is contained in the financial statements that are prepared at fair value next to the historical value in times of inflation.

And when you return to the accounting literature, we find accounting disclosure cares to publish economic information related to the project, whether quantitative or qualitative, in order to help the investor to take decisions to reduce uncertainty about future economic events.

I. (Soalha \& Ja'far, 2008) study entitled: "Transparent accounting disclosure and its impact on the performance of the company's value" the study clarified:

The effect of the level of transparency in information emanating from Jordanian public shareholding companies listed on the Amman financial market in the sectors of industry and services, and connects them with the performance of the company's accounting. The study was characterized by its containing to the sub-indices and comprehensive that measures the level of transparency: the governance general index , the index of disclosure and financial transparency, disclosure index composition of the management and operations. The study developed a model to assess and analyze the level of culture with the public shareholding companies in the sectors of industry and services and therefore this study are in contrast with previous studies in Jordan, which was to take the disclosure by adhering to legislation relating to disclosure and international accounting standards.

II. (Siam \& AlMuhanadi, 2007) study entitled: "The effect of accounting disclosure in the financial reports published on stock prices". An Empirical Study of industrial companies Jordanian public shareholding. Reached to:

The average level of disclosure of information contained in the published annual reports of the companies under study was $(73 \%)$ and that there was a relative improvement in the level of disclosure and researcher attributed the reason to the legislation governing the evolution of the process of disclosure. There is a positive direct correlation between level of disclosure in the annual financial reports and between total assets, annual sales volume and the number of shareholders. There is no relationship between the level of disclosure in annual reports and the percentage change in the stock price for the period surrounding the publication of annual reports on.

III. (Abdullah, Rabab'a \& Al-Zoubi, 2007) study entitled: "Provisions of corrupt broking in Islamic jurisprudence and the Jordanian Civil Code":

This research covers the reasons for the corruption of a speculation company, and the legality of corrupted speculation in Islamic Fiqh and in the Civil Law in Jordan. It discusses in detail the reasons for the corruption of a speculation company from the point of view of Islamic scholars (fuqaha') and from the point of view of the Civil Law in Jordan. Also covered, is the difference between a corrupted contract and an unlawful one. In addition, this research covers the legality of the behaviors of speculators after corruption of the company, and the results that occur before such an act or after it. The study illustrates the legal status of the laborer and the corruption effects of the speculation company and how to calculate the amount of profit in the corrupt speculation company.

\subsubsection{English Studies}

I. (Morris \& Gray, 2007) study entitled "corporate transparency differences in the Asian region the feasibility of global standardization in practice?" 
Using a unique hand-collected dataset covering 434 companies from 12 Asian countries in 2002, we examine whether countries matter more than firms in explaining variance in financial transparency. IFRS-based checklists of 228 and 441 items are used to measure transparency. Our data cover more companies per country, in much greater depth, than CLSA, CIFAR or Standard \& Poor's datasets. Both our transparency measures differ significantly across countries. Country-level variables matter more than firm-level variables in explaining variance in most model specifications. Legal system, bank-oriented economy and enforcement of standards matter most at the country-level. Firm complexity, debt raising, auditor-type, firms' international focus and foreign stock exchange listings are consistently associated with transparency at the firm level across model specifications. Our findings suggest that converging accounting practices in the region short-term will not be easy, although there are strong firm-level market-based forces driving transparency which may assist the convergence process long-term.

II. (Cheung et al., 2005) study entitled: "determinants of corporate disclosure and transparency evidence from Hong Kong and Thailand":

This study examines the degrees of corporate disclosure and transparency of publicly listed companies in two emerging markets and analyzes corporate disclosure practices as a function of specific firm characteristics. The analysis uses the disclosure and transparency scores extracted from a survey instrument designed to rate disclosure practices of publicly listed companies by using the OECD Corporate Governance Principles as an implicit benchmark. Empirical results show that financial characteristics explain some of the variation in the degrees of corporate disclosure for firms in Hong Kong but not for firms in Thailand. Further, corporate governance characteristics, such as board size and board composition show more significant associations with the degrees of corporate disclosure in Thailand than in Hong Kong. The results are broadly consistent with the notion that good corporate governance leads to better corporate disclosure and transparency in less developed markets.

III. (Kim, 2005) study entitled: "Accounting transparency of Korean firms: measurement and determinant analysis":

IV. (Dallas \& Patel, 2002) study titled: "transparency and disclosure overview of methodology and study results united states" reached to: Dramatic differences in how much companies disclose, both among regions and countries and within regions and countries. In the U.S., there is a notable difference between the T\&D rankings based on annual reports alone and T\&D rankings on a composite basis. The amount of information companies provide in their annual reports is correlated to market risk and valuations. Non-financial disclosure in annual reports needs improvement.

\subsubsection{Procedural Definitions}

\section{i. Broking company:}

It is a contract on partnership among two parties, one of them provide money (Partnership in the money) and other provide work (partnership) work is with trade and profit and it is contract on cash to disposition in it trader.

\section{ii. Accounting disclosure}

Presentation of information that has a significant effect on the users of financial reports, so that the financial statements are prepared in a manner depicted economic events that have affected the company during a certain period of time. And displayed for all categories in the same class and so gets all the users of annual reports on the same degree of disclosure and at the same time.

\section{iii. Broking}

One of parties from the contract in broking company, he is working in broking partnership in order to obtain the profit and he is the agent of owner in his money.

\section{iv. Owner}

One of parties in broking company which provide the money for broking to obtain the profit and bear the resulted loss in working.

\subsubsection{Hypothesis of Research}

i. The accounting disclosure in broking companies for information that will help observers to the unit economics to take appropriate and right decisions.

ii. Current financial statements that prepared for broking companies don't provide terms of appropriate accounting disclosure. 


\subsubsection{Methodology}

The researchers sought to achieve research aims, they used inductive approach through the study of a set of definitions, concepts, terms related to broking companies, their essential role in the community as well as the basic principles and problems arising from the broking contract. The concept of accounting disclosure in broking company, show the intellectual framework about the concept of disclosure, its role in accounting media, terms of appropriate discloser and the observe the common area between these groups to reach to the results that should put suitable solutions lately.

\section{Analysis and Induction}

Study the following questions must be analyzed and inducted:

i. How to measure and identify all of the expenses, revenues, assets, liabilities, owners' equity and disclosed in companies?

ii. How do you measure, determine, the distribution of profits, losses and disclosed in the broking company?

iii. What are the basic components for the disclosure of accounting information in Broking Company?

iv. What is the role of accounting disclosure in making accounting information more useful to decision makers in Broking Company?

v. What are the rules of disclosure of information in Broking Company?

\section{Expenses}

Expenses can be determined to be disclosed in Broking Company to the following approach:

i. Wages and salaries: workers and staff worth wages to meet their work that associated with them the Messenger of Allah peace be upon him have recommended by saying: "give the employee his wages before his sweat dries " for achieve social and economic purposes. The wades may be cash or material and wages should be known.

ii. Advertising: Taking into account the marketing literature in Islam in terms of honesty and show defects Item.

iii. Brokerage commissions: Brokerage commission at purchases and sales.

iv. Discounts on purchases and sales.

v. Improvement expenses: investment costs are those that lead to improve the asset not only to maintain it lead to any increase in its value.

vi. Maintenance expenses: expenses spent on origin to return to its condition. Or preventive maintenance.

vii. Travel expenses and transition: provided that the travel for broking purposes agreed between the parties.

viii. rental expenses or vacation or storage and transition

ix. Bad debt and doubtful

\section{x. Depreciation}

xi. Consumption: the assets circulating in trade, which was prepared for the sale.

xii. Personal withdrawals: personal withdrawals are not considered from costs of production.

\section{Revenue}

Revenue is affected positively or negatively by a factor of quality and kind of cost which close to the markets, revenue ranging in Islamic companies such as: Namaa (growth of plants) Netaj (Animal product) profit (trade profit) gain (industrial gains).

Profit: Gains and losses in Broking

Broking is a contract between two parties; it is a contract on profit. Profit gains in general, either with money or work or insurance in broking, profit is worth by money (owner share) and work (broker share).

Some scholars in profit suggest what follow to say that broking contract is correct:

i. The share of each party is known when contracting.

ii. Profit should be shared between contractors, so no one of them specializes in field without other.

iii. The distribution of profit is common share for each broker and owner of money, Have their share of the profit share common fair or a third of it or any part of a common mutually agreed. 
iv. Both parties agreed that the loss in the responsibility of the owner of the money who has the capital where the worker does not bear anything, as long as he will not shorten or violates the conditions.

Profit then, is the increase in net property during a specified time period, or happening development in value. The profit represents at measurement procedure at the end of the specific period and explained the need for separation between the courses by the extracted separation and gaining.They distinguish between the types of development according to profit concept with current meanings. Development types are: profit, interest and profit-offs.

Profit: normal profit: it is the development which resulting from the well-behaved administration and organization.

Interest: Capital Gains: Development is caused by the high prices of fixed assets.

profit-offs: Development is caused by traded rising asset prices.

\subsection{Time and Its Impact on Profits}

The time is the time long or short and can be determined a space with the period of time. The profit measure established by measuring the, project or individual ownership status between two time periods.

First: The selected user for the accounting information in broking company as broker, owner, analysis, research, staff, debt, government, investor and other. Identify the user helping in defined the characteristics according to form and contain, that for the difference efficiency in users in the interpretation of financial statements accounting information.

Second: Determine to make accounting information useful that should link the purpose that we can used in it accounting information with appropriate standards, where this characteristic determine the nature or the type of accounting information.

Third: Determine the nature of the information that must be disclosed: The financial statements (statement of financial position, income statement, a list of retained earnings, statement of changes in equity, cash flow statement).

Fourth: Determine the methods and ways of disclosure of accounting information, Requires appropriate disclosure in the presentation of information in the financial statements in ways that are easy to understand and easy to require also arrange and organize information in a logical manner which focuses on the core things so that the user can easily read the target. Presentation the information plays an important role in the process of easily understood by the user of this information, so it requires appropriate disclosure that the information is displayed in ways that are easy to understand.

Fifth: The disclosure timing of accounting information ,In accounting convention the disclosure of information is at the end of the fiscal year of the facility. Legislation for most states have required, a specific period maximum to publish financial statements of joint stock companies after the end of its fiscal year so that it can take advantage of existing information on the financial statements is the timing of the disclosure of information is very important for user information .

International standard No (1) deal with presentation of financial statements and deal with the information that should be disclosed in financial statements according to form and content.

We will address the rules for the balance sheet, which can be divided as follows:

i. Non-current assets:

Assets which is not prepared for fully consumption or use during normal operating cycle of the facility and acquired for the operation of the facility, such as property, plant, equipment, intangible assets, long-term investments , non-current assets held for sale and assets that have been purchased in installments.

ii. Current assets:

An asset held for the purposes of collection, sale or use or traded during normal operating cycle of the business such as cash and short-term investments, inventory, accounts receivable and debt prepayments.

iii. Liabilities

a. Current liabilities:

Benefits during the operational cycle or fiscal year and can not postpone repayment for the year or held for trading purposes. 


\section{b. Non-current liabilities:}

An asset that has not been repaid during the operating cycle or fiscal year can postpone repayment does not keep them for the purposes of trading, such as bonds, notes payable, long-term deferred income and pensions.

1) For Shareholders Equity: the disclosure of capital, Retained earnings and reserves.

2) Income statements:

- The results of the business of the profit or loss in the income statement, the income is the increase in economic benefits during the accounting period, which lead to increased property rights, except for contributions.

- The definition of income includes both revenue and gains. Referred to as revenue under different trade names including sales, fees, interest, dividends and royalties and franchise rent.

\section{Results and Recommendations}

\subsection{Conclusions}

i. Accounting discourse in broking companies could be through financial statements that's is required by international accounting standards And accounting information are presented in the financial statements in an easy ways to arrange and organize information in a logical manner mindful of accounting policies and the nature of the accounting unit and subsequent events, making it easier on the user to make rational decisions.

ii. May identify the elements of expenses to be disclosed in broken companies in accordance with the requirements According to the requirements of the preparation of the income statement prepared in accordance with accounting standards discourse with statement that the measure expenses may be in cash or a monthly or annually amount.

iii. Treatment accounting of depreciation expense of fixed assets differ from depreciation expense for assets traded in broker companies where may not establish income statement with expense of depreciation of fixed assets, because it lowers the value of the net profit, which will be shared between the broker and owner of the money and just load it on the owner's money share While consumption of assets intended for sale in the process of broking can be loaded on the revenues of the financial period.

iv. Period revenues be include in the income statement with the value that has been gained with the use of analytical methods in determining expected revenues, as well as measuring the stock of last of the period goods on the basis of proverb price .

v. Profit will be shared between the owner and broker according to the conditions that were agreed upon in the distribution of earnings and profits in broking companies is the increase of the capital And not be distributed until determining capital and dissolution of the company if it is given to the owner of the capital first and then be sharing the profits and losses will be on the owner only and the profit must be known and distributed in common shares between them.

vi. May not distribute any profit unless it delivers the invested capital to the owner and the distribution is considered null if distributed. And the two parties of the contract must attend when distributing.

vii. Time period differs to measure the work results by the nature of the work for example (alkharaj) which is a tax paid on lands expressed in hijra year, and planting areas expressed in solar year.

viii. The basic elements of the accounting disclosure in broking companies depends on the body that use financial information and the purpose of the accounting information and the techniques and methods of disclosing of accounting information.

\subsection{Recommendations}

In the light of results researchers recommend the following:

i. Re-include the laws relating to disclosure the items that increase the level of transparency so that forcing broking companies to disclose the policies and accounting procedures followed to increase the level of transparency of disclosing and activate companies to apply government principles . and show the origins in basic independent groups and illustrate in each group its constitute elements and according to the requirements of accounting disclosure. And clarify of finished goods and under activation goods and raw materials . and distinguish between current assets and non-current assets. And show obligations and property rights in independent groups and according to the requirements of accounting disclosure.

ii. Drawing the attention of investors to the importance of disclosed information in broking companies and its impact on the process of making investment decisions and the regulators of the capital market to make efforts in 
order to increase the non-financial disclosure in companies and work on strengthen and promoting it like entering new aspects and discloses like disclosing about human resources.

iii. Holding workshops and conferences to raise awareness about the importance and role of broking companies . and the importance of accounting disclouser in guiding and raising accounting awareness which support making the rational decision.

iv. Call researchers to do more studies and researches about broking companies in general and the transparency of disclosure accounting in particular and apply it on different sectors or introduction of other variables that help in explaining the different levels of disclosure transparency among companies.

\section{References}

Aksu, M., \& Arman, K. (2006). Transparency and disclosure scores and their determinants in the Istanbul Stock exchange. Corporate Governance: An International Review, 14(4), 277-296. http://dx.doi.org/10.1111/j.1467-8683.2006.00507.x

Ang, J. S., \& Ciccone, S. J. (2001). International differences in financial transparency. $\mathrm{PhD}$ dissertation. Florida State University, Department of Finance, Bank of Chicago. Retrieved from http://www.federalreserve

Berglof, E., \& Pajuste, A. (2005). What do firms disclose and why? Enforcing corporate governance and transparency in Central and Eastern Europe. Working paper, Stockholm School of Economics.

Brown, L. D., \& Caylor, M. L. (2004). Corporate governance and firm performance. Working paper, Georgia State University.

Bushman, R. M., \& Smith, A. J. (2003). Transparency, Financial Accounting Information, and Corporate Governance. Economic Policy Review, 9, 65-87.

Bushman, R. M., Piotroski, J. D., \& Smith, A. J. (2004). What determines corporate transparency? Journal of Accounting Research, 42, 207-252. http://dx.doi.org/10.1111/j.1475-679X.2004.00136.x

Cheung, S. Y., Connelly, J. T., Limpaphay, P., \& Zhou, L. (2005). Determinants of corporate disclosure and transparency: Evidence from Hong Kong and Thailand. Working Papers. http://dx.doi.org/10.1596/1813-9450-3763

Choi, F. (1972). Financial disclosure and entry to the European capital market. Journal of Accounting Research, 11(2), 159-173. http://dx.doi.org/10.2307/2490187

Gass, D. (2006, December). Importance of transparency in financial reporting. Retrieved March 10, 2008, from http://ezinearticles.com/?Importance-Of-Transparency-In-Financial-Reporting\&id=376424

Gray, S. J. (1988). Towards a theory of culture influence on his development.

Greenspan, A. (2003). Remarks. Delivered via satellite at the 39th.

Hendrickson, E. (1982). Accounting theory (4th ed.). Homewood: Richard d. Irwin.

Kim, J. (2005). Accounting transparency of Korean firms: Measurement and determinant analysis. The Journal of American Academy of Business, 2, 222-229.

Morris, R. D., \& Gray, S. J. (2007, March). Corporate transparency differences in the Asian region: The feasibility of global standardization in practice. Australian Research Council Discovery Grant, Work Papers.

Patel, S. A., \& Dallas, G. (2002). Transparency and disclosure: Overview of methodology and study resultsUnited States. New York: Standard \& Poor's.

Radebaugh, L., \& Grary, S. (2002). International accounting and multinational enterprises (5th ed.). John Wiley and Sons Inc.

Sadka, G. (2004). Financial reporting, growth, and productivity: Theory and international evidence. Working paper, University of Chicago. Retrieved from http://papers.ssrn.com/paper.taf?abstract_id=652301

\section{Copyrights}

Copyright for this article is retained by the author(s), with first publication rights granted to the journal.

This is an open-access article distributed under the terms and conditions of the Creative Commons Attribution license (http://creativecommons.org/licenses/by/3.0/). 